\title{
Effects of Time of Earthing Up on Yield and Yield Parameters of Irish Potato (Solanum Tuberosum L.) in Zaka District, Zimbabwe
}

\author{
Nyasha Sakadzo ${ }^{1}$, Fortune Tafirenyika ${ }^{1} \&$ Kasirayi Makaza ${ }^{1}$ \\ ${ }^{1}$ Department of Soil and Plant Sciences, Faculty of Agricultural and Natural Sciences, Great Zimbabwe University, \\ Zimbabwe \\ Correspondence: Nyasha Sakadzo, Department of Soil and Plant Sciences. Faculty of Agricultural and Natural \\ Sciences, Great Zimbabwe University, P.O. Box 1235 Masvingo, Zimbabwe. Tel: 263-775-985-724. E-mail: \\ nsakadzo87@gmail.com
}

Received: December 7, 2019 Accepted: December 27, 2019 Online Published: January 1, 2020

\begin{abstract}
Potato (Solanum tuberosum L) is a strategic national food security crop in that can be used as a supplement for carbohydrates. It is the fastest growing staple food crop and source of income for poor smallholder farmers. There is limited documentation on effects of earthing up irish potatoes on yield and yield components in Zimbabwe. A field experiment was conducted in Zaka district of Masvingo province in Zimbabwe during the 2018/19 cropping season. The aim of the study was to investigate the effect of time of earthing up on yield and yield parameters of BP1 potato variety. The treatments consisted of four levels of time of earthing up (no earthing up (control), three, four and five weeks after plant emergence), replicated three times on a Randomized Complete Block Design (RCBD). Results on earthing-up at three weeks recorded significantly $(\mathrm{P}<0.013)$ the highest total tuber yield $\left(21.97 \mathrm{t} \mathrm{ha}^{-1}\right)$ which is $10 \%$ higher compared to no earthing up which recorded $14.43 \mathrm{t} \mathrm{ha}^{-1}$. Moreover, earthing up at two weeks had the least number of greening tuber yield (3\%), $11 \%$ pest damaged tuber yield, $6 \%$ unmarketable tuber yield and $45 \%$ marketable tuber yield. This is in contrast with no earthing up which recorded $91 \%$ greening tuber yield, $25.3 \%$ on pest damaged tubers, $59 \%$ on unmarketable tubers and $10 \%$ marketable tuber yield. Based on the results, first earthing up should be done at three weeks after complete plant emergence at the study area under rain fed conditions for the production of potatoes with improved yield and better tuber quality.
\end{abstract}

Keywords: Potato (Solanum tuberosum L.), small holder farmers, food security, tuber yield, hilling, time of earthing up

\section{Introduction}

Potato (Solanum tuberosum L.) is an herbaceous annual plant which belongs to the order Solanales in the Solanaceae family of flowering plants grown for its edible tubers. It was first cultivated 6000 years ago by the Inca tribe in Peru (Quin, 2011). The potato plant has a branched stem and alternately arranged leaves consisting of leaflets which are both of unequal size and shape. It produces white or blue flowers and yellow-green berries. The potato tubers grow underground and are generally located in the top $25 \mathrm{~cm}$ of the soil, (Burke, 2012). The tubers can range in color from yellow to red or purple depending on the variety. Potato may also be referred to as, spud, Irish potato, white potato or Spanish potato. The plants can reach in excess of $1 \mathrm{~m}$ in height (Gusha, 2014).

Irish potato (Solunum tuberosum L.) Irish potato is the most important horticultural crop in Zimbabwe and third as a carbohydrate food source after maize and wheat (Masvodza, 2015, The Herald, 2011, Ackerman, 2013). Acknowledging the increased interest in potato production and consumption, the Government of Zimbabwe declared Irish potato a national strategic food security crop on 18 May 2012 (The herald, 2012, Svubure et al., 2015).

In contemporary Zimbabwe Irish potatoes were well established by the early twentieth century (FAOSTAT, 2012). In the year 1911, variety trials were undertaken with recorded yields up to 11.5 tones/ha. The government then decided to monitor local potato production as a priority to avoid the introduction of pests that may hinder the production of tobacco, one of Zimbabwe's most profitable cash crops (Masvodza, 2015) Therefore, the production of Irish potatoes in the country is protected under the Plant Pests and Diseases (Seed Potato Protection) Regulations in Statutory Instrument 679 (1982), although farmers themselves bear the responsibility to safeguarding their crop from diseases. Additionally, a national breeding program, which subjects imported potatoes to heavy quarantine, was instituted in 1956 and has been the only such program that is authorized to do so. 
Today, potato production and consumption are booming worldwide, with ever greater quantities being processed for food and snack industries, while its importance as a subsistence crop continues to expand, (Muhammad et al., 2013). The average composition of the potato is about $80 \%$ water, $2 \%$ protein, and $18 \% \mathrm{starch}$. As a food, it is one of the cheapest and easily available sources of carbohydrates and proteins and contains appreciable amount of vitamins B and C as well as some minerals. According to FAO (2008), potato is the world's leading vegetable crop and is grown in $79 \%$ of the world's countries. More than a billion people consume it almost daily. Hundreds of millions of people in developing countries depend on potatoes for their survival, (Muhammad et al., 2013)

Several factors have been associated with reduced potato yields, with a lack of knowledge on time of earthing up and cultivation methods as well as the rising costs of production as major factors (Masvodza, 2015). According to Svubure et al. (2015), a study on yield gap analysis and resource footprints of Irish potato production systems in Zimbabwe by the Field Crops Research in 2015 found that most farmers lacked the technical know-how, about potato-farming. FAOSTAT (2013) postulated that about 3,500 hectare of the crop is planted annually in Zimbabwe; the average yield for potatoes is 20 tones per hectare. Currently there is little documentation on effects of earthing up of potatoes. Therefore, the objective of this research project is to assess the influence of time of earthing up on yield and yield parameters of Irish potatoes in Zaka district.

\section{Materials and Methods}

\subsection{Study site}

The study was carried out in Zaka district in Jerera growth point plot number 353 which is $\left(20^{\circ} 24^{1}\right.$ South and $31^{\circ}$ $26^{1}$ East) at an altitude of 731 meters above sea level (Figure 1 shaded in orange). The site is located 104 kilometers South East of Masvingo town in Natural Region iv of Zimbabwe. The area is characterized by erratic rainfall pattern and the variability of rainfall and shortness of the season. The average annual rainfall ranges from 450-600mm per year. The area is dominated by sand loamy of granite origin soils with a pH ranging from 5.5- 6.5.

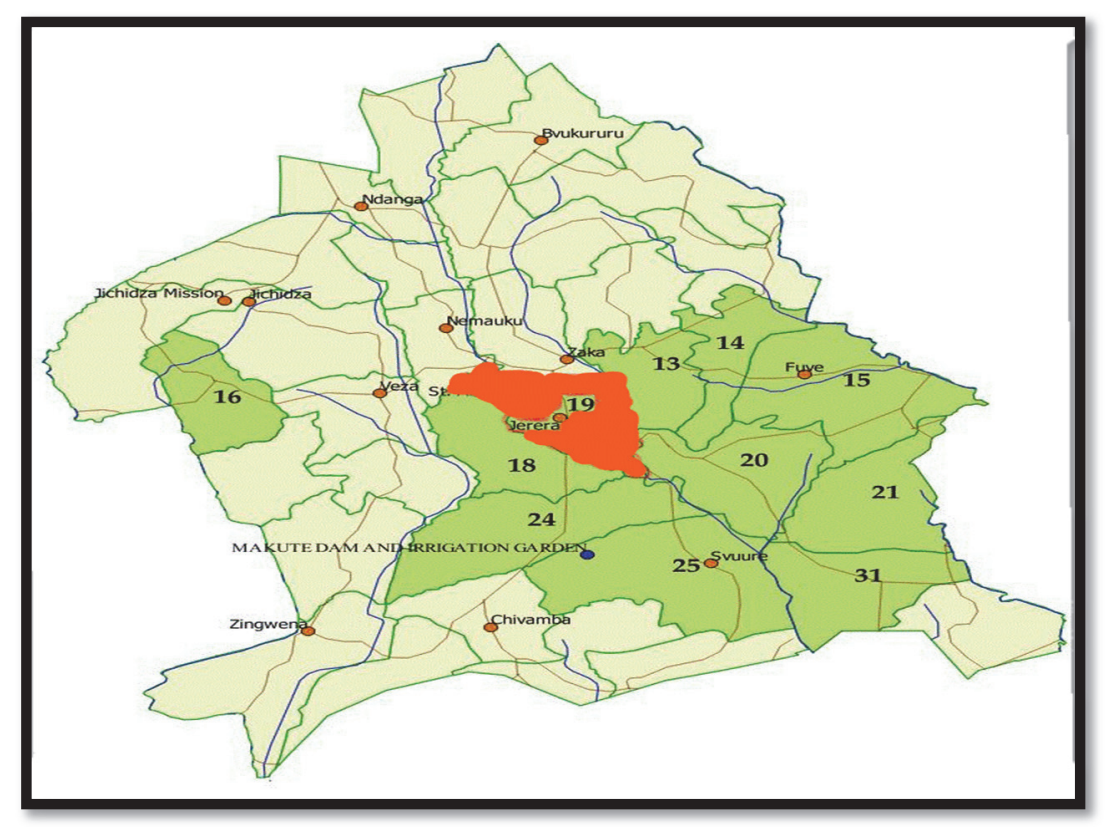

Figure 1. Study site map (shaded in orange)

\subsection{Experimental Design}

The experiment was implemented in a Randomized Complete Block Design (RCBD) as postulated by Tesfaye $e t$ al. (2013). The experimental design had four treatments replicated three times. The treatments of the experiment are shown in table 1 below: 
Table 1. Treatment structure.

\begin{tabular}{|c|c|c|c|}
\hline & Treatment & & \\
\hline $\mathrm{T} 1$ & $\mathrm{~T} 2$ & $\mathrm{~T} 3$ & $\mathrm{~T} 4$ \\
\hline $\begin{array}{l}\text { No earthing } \\
\text { up(control) }\end{array}$ & $\begin{array}{l}\text { Earthing up a week before } \\
\text { flowering }\end{array}$ & Earthing up at flowering & $\begin{array}{l}\text { Earthing up a week after } \\
\text { flowering }\end{array}$ \\
\hline Weeks & 3 weeks after plant emergence & $\begin{array}{l}4 \text { weeks after plant } \\
\text { emergence }\end{array}$ & $\begin{array}{l}\begin{array}{l}\text { 5weeks after plant } \\
\text { emergence }\end{array} \\
\end{array}$ \\
\hline
\end{tabular}

\subsection{Plot Management}

\section{Plot layout}

Three plots (blocks) were designed, each block comprised of 4 rows of $3 \mathrm{~m}$ in length spaced at $0.9 \mathrm{~m}$ apart. The in-row spacing was $0.3 \mathrm{~m}$ and $0.9 \mathrm{~m}$ inter-row. A total of 40 sprouted seed potato tubers of the BP1 variety were sown in each block allowing two shoots to grow per planting station. BP1 is a local early maturing variety which takes about 14-15 weeks to mature with white skin and flesh. The variety is resistant to late blight and has an expected yield of 13.5 to 20thaThe four treatments were replicated three times randomly to make a total of 12 rows in 3 blocks.

\section{Fertilizer application}

Compound S basal dressing fertiliser (NPK: 7:21:7) was used at planting at a rate of $1300 \mathrm{~kg} / \mathrm{ha}$. Ammonium nitrate $(\mathrm{AN})$ will be used as top dressing at a rate of $150 \mathrm{~kg} / \mathrm{ha}$. The rate of AN

\section{Data collection and statistical analysis}

Some Irish potato parameters were recorded which have been documented to influence yield and other yield parameters, for example number of greening tubers (NGT), number of pest damaged potatoes (NPDT), number of unmarketable tubers (NUMT) and number of marketable tubers (NMT) and plant height. Analysis of variance was done using GenStat statistical package $14^{\text {th }}$ edition. Separation of means was done using Fisher's protected least significant difference (LSD) test at 5\% significant difference.

\section{Results}

Table 2. Effects of time of earthing up on yield and yield parameters of Irish potatoes.

\begin{tabular}{|c|c|c|c|c|c|c|}
\hline Treatment & $\begin{array}{l}\text { Number of } \\
\text { pest damaged } \\
\text { tubers } \\
\text { (NPDT) }\end{array}$ & $\begin{array}{l}\text { Number of } \\
\text { marketable } \\
\text { tubers } \\
\text { (NMT) }\end{array}$ & $\begin{array}{l}\text { Number of } \\
\text { unmarketable } \\
\text { tubers } \\
\text { (NUMT) }\end{array}$ & $\begin{array}{l}\text { Number of } \\
\text { greening } \\
\text { tubers } \\
\text { (NGT) }\end{array}$ & $\begin{array}{l}\text { Weight of } \\
\text { fresh tubers } \\
(\mathrm{Kg})(\mathrm{WFT})\end{array}$ & Yield t/ha \\
\hline NEU (Control) & $25.33^{b}$ & $32.7^{\mathrm{a}}$ & $128.0^{\mathrm{a}}$ & $125.00^{\mathrm{b}}$ & $3.47^{\mathrm{a}}$ & $14.43^{\mathrm{a}}$ \\
\hline EUBF (3 weeks) & $4.67^{\mathrm{a}}$ & $151.7^{\mathrm{d}}$ & $13.3^{\mathrm{d}}$ & $4.00^{\mathrm{a}}$ & $5.27^{\mathrm{b}}$ & $21.97^{\mathrm{c}}$ \\
\hline EAF (4 weeks) & $6.00^{\mathrm{a}}$ & $93.7^{\mathrm{c}}$ & $24.7^{\mathrm{c}}$ & $3.67^{\mathrm{a}}$ & $4.50^{b}$ & $18.73 \mathrm{bc}$ \\
\hline EUAF (5 weeks) & $5.33^{\mathrm{a}}$ & $59.0^{\mathrm{b}}$ & $49.3^{b}$ & $4.00^{\mathrm{a}}$ & $4.40^{b}$ & $18.33^{b}$ \\
\hline Grand Mean & 10.33 & 84.2 & 53.8 & 34.17 & 4.41 & 18.37 \\
\hline LSD & 1.97 & 14.30 & 11.64 & 5.68 & 0.87 & 3.6 \\
\hline P Value & $<0.001$ & $<0.001$ & $<0.001$ & $<0.001$ & 0.014 & 0.013 \\
\hline $\mathrm{CV} \%$ & 9.8 & 3.1 & 4.7 & 4.2 & 6.1 & 6.0 \\
\hline
\end{tabular}

*Mean values followed by the same letter in a column are not significantly different at $5 \%$ level according to Fisher's protected least significant difference test.

\section{Effects of time of earthing up on the yield of Irish potatoes (t/ha)}

Results on table two indicated that there were significant differences $(\mathrm{p}<0.05)$ amongst the treatments. Earthing up before emergence (EUBF) treatment managed to reach 21.9tons per hectare which was higher than not earthed up (NEU) (control) which had 14.4 t/ha (Figure 2). 


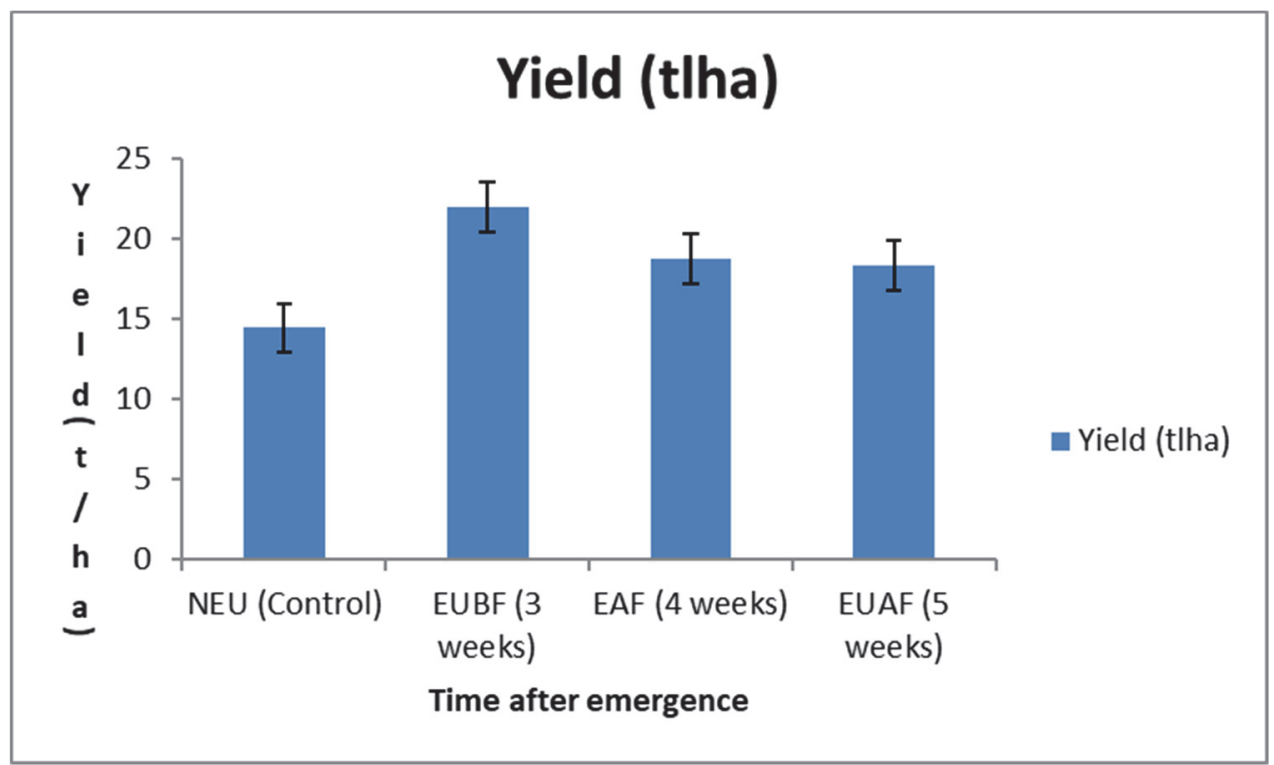

Figure 2. Bar graph showing effects of time of earthing up on the yield of Irish potatoes

\section{Effects of time of earthing up on number of pest damaged tubers (NPDT).}

The results showed that there were significant differences amongst the treatments $(\mathrm{P}<0.001)$ on number of pest damaged tubers (NPDT). Although the treatment means of EUBF, Earthed at flowering (EAF) and Earthed up after flowering (EUAF) showed no statistical difference as shown in table 2 above, the control NEU had 25.3 of its tubers damaged by pests while other treatments three weeks, four weeks and five weeks had 4.6, 6.0 and 5.3 tubers which were pest damaged.

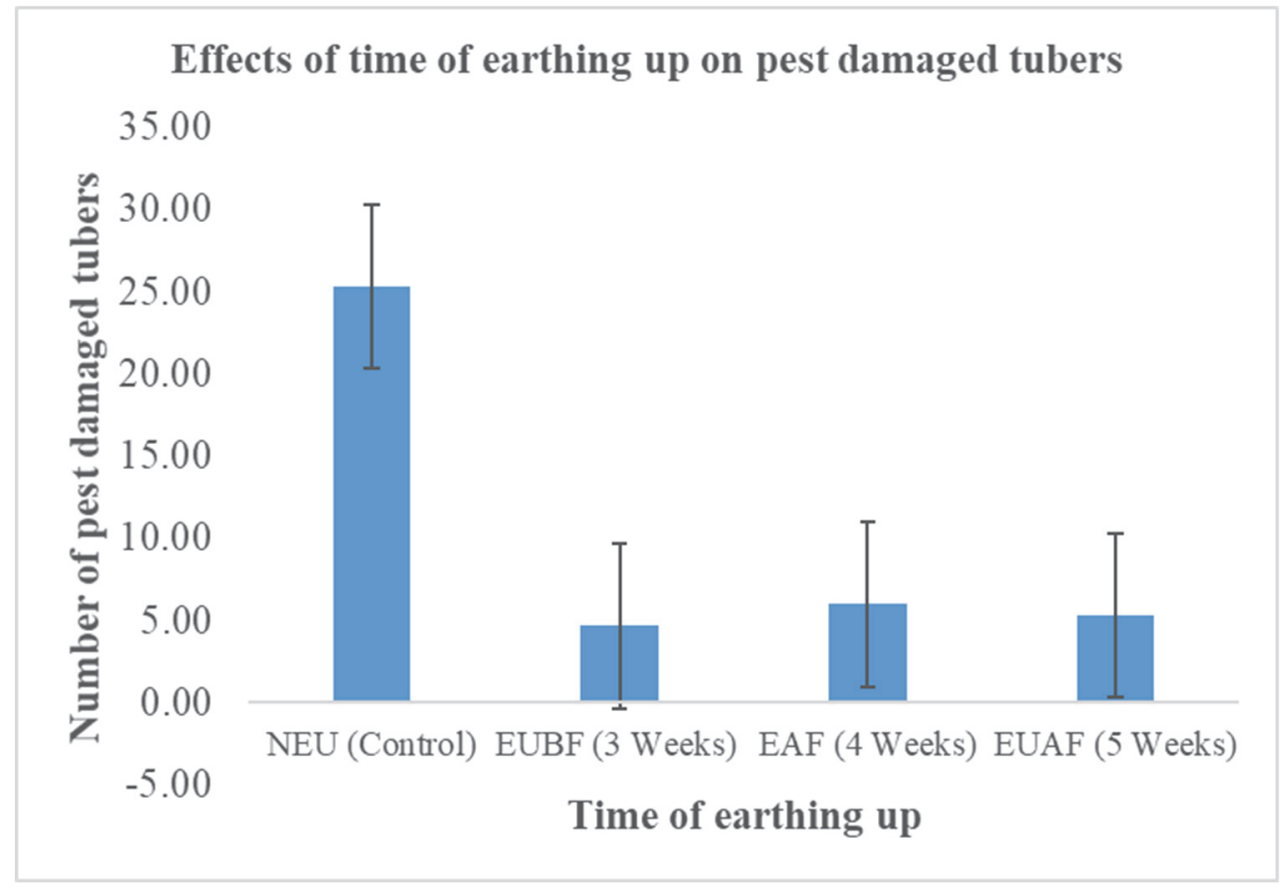

Figure 3. Bar graph showing effects of time of earthing up on number of pest damaged tubers

\section{Effect of time of earthing up on number of greening tubers (NGT)}

Results indicated that there were highly significant differences $(\mathrm{p}<0.001)$ amongst the treatments as shown on table 1. The NEU (Control) recorded the highest number of greening tubers (125) which is $91 \%$ of the total 
greening tubers of the treatments against $3 \%$ on each of the remaining 3 treatments.

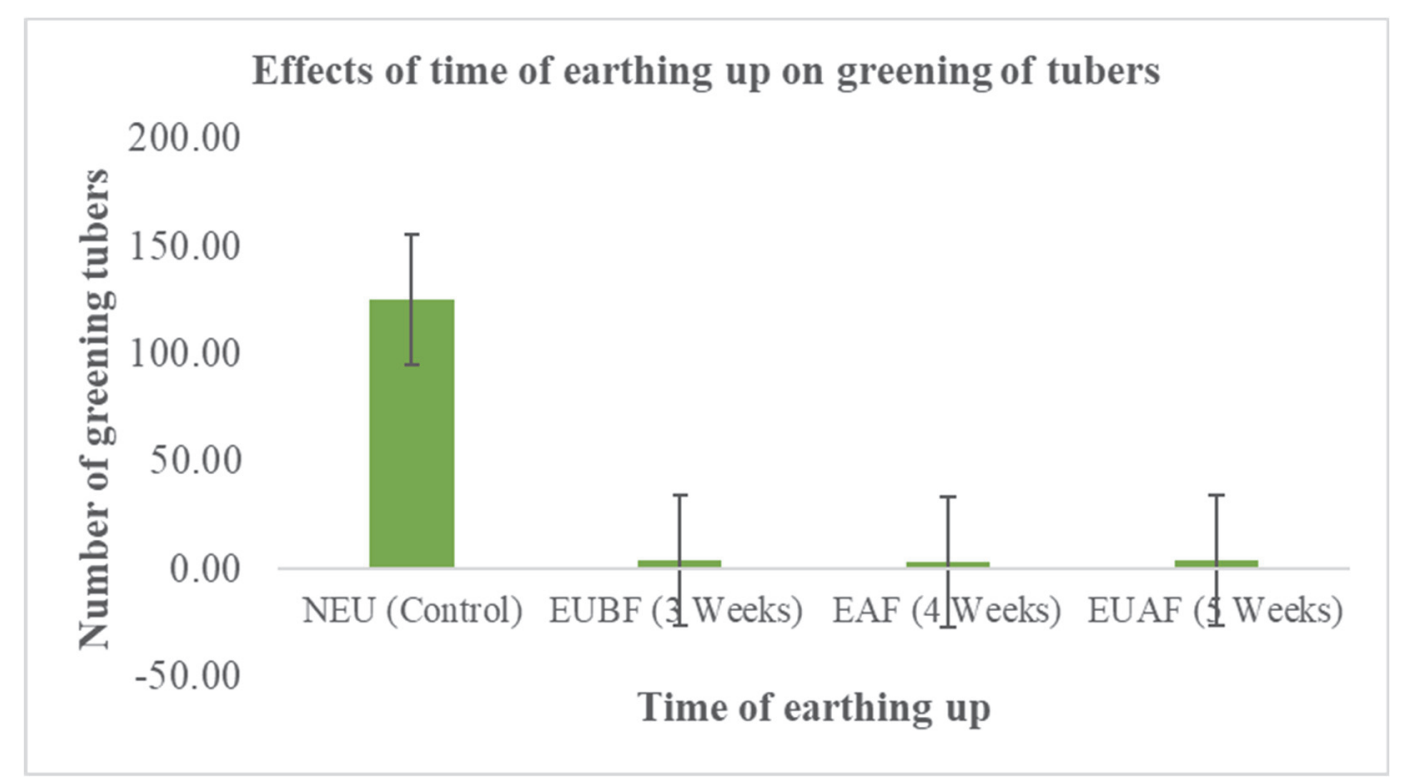

Figure 4. Bar graph showing e effects of time of earthing up on number of greening tubers

\section{Effects of time of earthing up on number of unmarketable tubers (NUMT).}

Results showed that there were significant differences $(\mathrm{p}<0.05)$ amongst the treatments as indicated on table 2 . The NEU (Control) treatment recorded the highest number of unmarketable tubers (128) whilst EUBF scored the least (13.3).

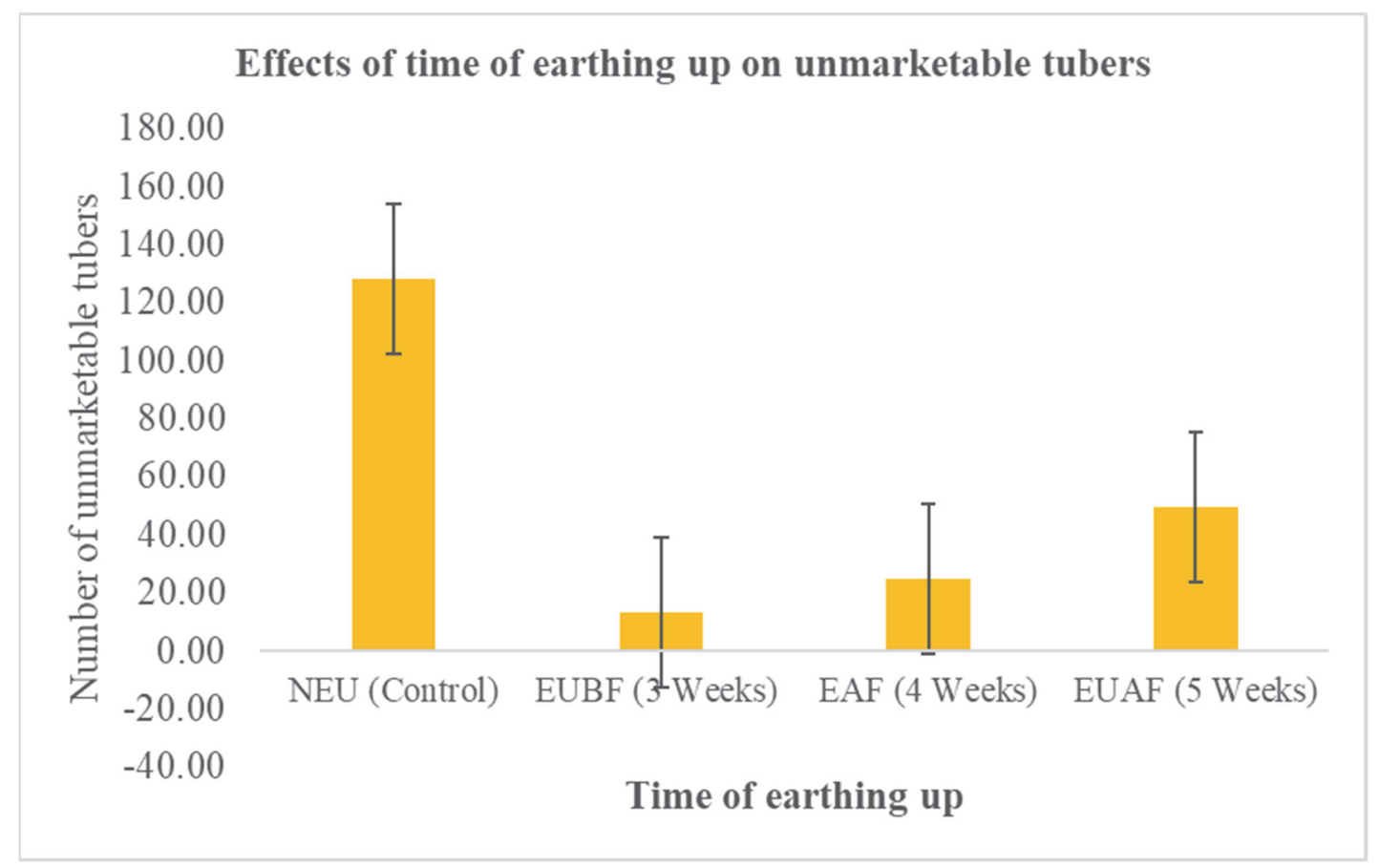

Figure 5. Bar graph showing effects of time of earthing up on unmarketable tubers 


\section{Effects of time of earthing up on number of marketable tubers (NMT)}

Results showed that there were significant differences $(p<0.05)$ amongst the treatments as exhibited on table 2. Earthing up before flowering (EUBF) had the highest number of marketable tubers (152) whilst the control (NEU) had the least (33).

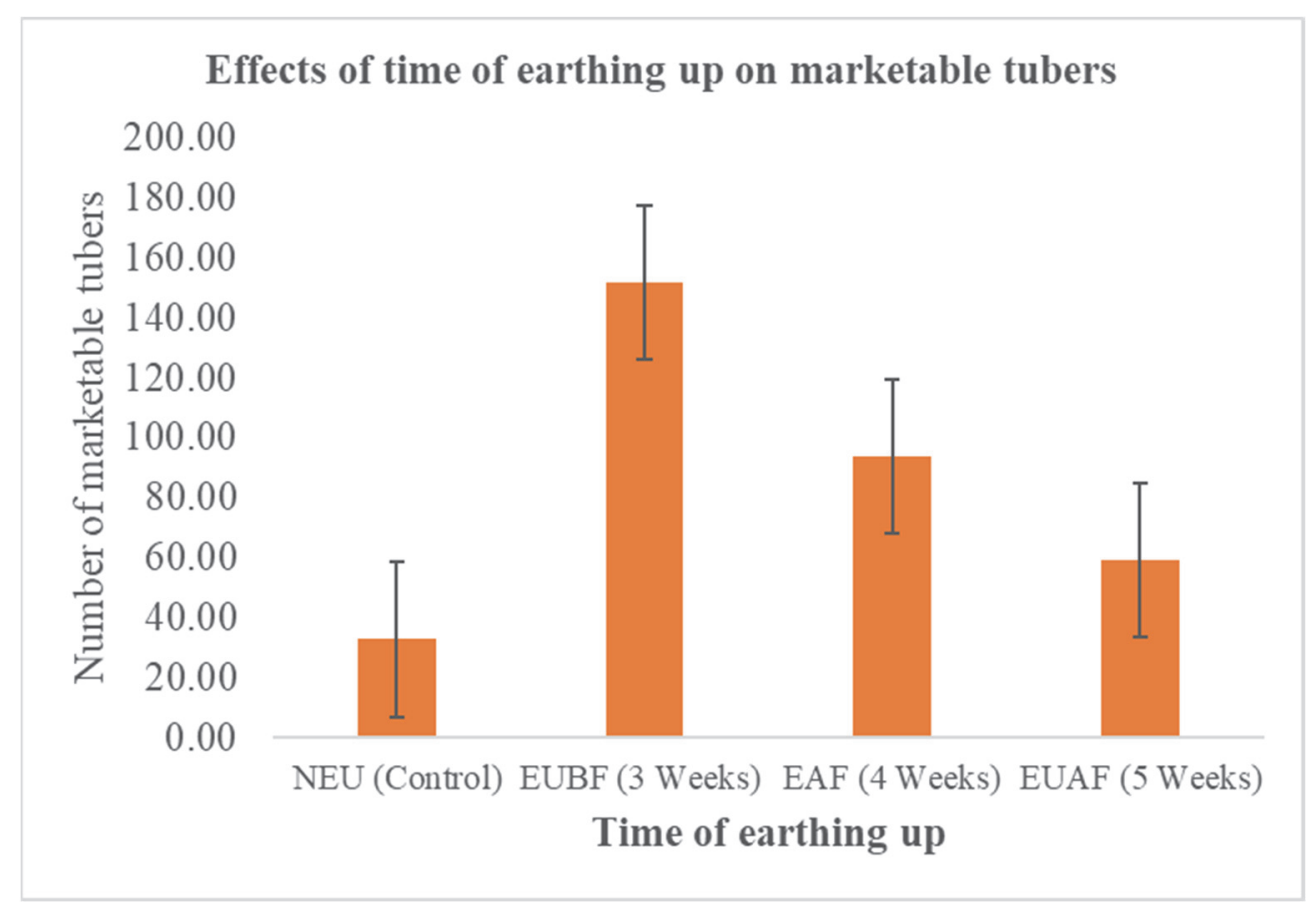

Figure 6. Bar graph showing effects of time of earthing up on number of marketable tubers

\section{Discussion}

\section{Effects of time of earthing up on Irish potato yield ( $t / h a)$}

Earthing up before flowering (EUBF 3 weeks) yielded $21.97 \mathrm{t} / \mathrm{ha}$ (30\%) while no earthing up (NEU control) recorded $14.43 \mathrm{t} / \mathrm{ha}(10 \%)$. This result is similar with that of

Gutema (2016) who obtained that ridging at two weeks after emergence during the growing period of the crop increased tuber yield by $10-20 \%$ compared to the control. In addition, Fanos et al. (2015) are also in agreement with this result through their study which they obtained that earthing up at 15 days give a difference of $10.13 \%$ on total potato tuber yield over the control with no earthing up. This is largely because of the enough time given to the potato plant (earthed at 15 days) to transform the photosynthesates to yield (a conducive environment for better source to sink relationship in the potato plants). In line with the study (Tafirt et al., 2010) explains the mutual effect of earthing up at 15 days as significant because it coincides with the active growth stage of the plant hence improved the soil conditions at this stage promotes efficient nutrient absorption resulting in increased plant growth and development that ultimately results in yield. According to Don and James (1990) the plant's severe need of the soil moisture and nutrients at this stage (two weeks), earthing up, thus, creates a suitable environment for growth of rhizomes and promote more tuber initiation.

\section{Effects of time of earthing up on number of pest damaged tubers}

The results showed that the difference amongst the treatments with respect to number of pest damaged tubers (NPDT) was highly significant. No earthing up (NEU) recorded $61 \%$ of the total pest damaged tubers among the treatments while other treatments ranged from $11 \%$ to $15 \%$. According to Svubureet al. (2015), potato tubers covered with soil less than $5 \mathrm{~cm}$ will be exposed and prone to pest attack. However, Singh and Joshi (2016) specified that the Irish potato plant has the ability to produce its own protective chemicals which can make it lethal to insects, animals and fungi which attack it. 


\section{Effects of time of earthing up on the number greening tubers}

There was a highly significant difference on the number of greening tubers amongst the treatments. A total of $91 \%$ of greening potatoes were recorded on (NEU) while $6 \%$ was recorded under earthing up before flowering (EUBF/3 weeks) treatment. The results concurs with the findings of Muhammad et al. (2013) who reported that ridging significantly reduced tuber greening, green tubers were found on plants where there was no hilling and was significantly more than any of the hilled treatments. When potato tubers are exposed to light, amyloplasts are converted to chloroplasts in tuber peripheral cell layers, which cause the accumulation of the green photosynthetic pigment (Fanos et al., 2015). Tuber greening can be impacted by genetic, cultural, physiological and environmental factors but planting depth and tuber physiological age, matters most (Singh \& Joshi, 2016). Tuber greening was reduced as seed pieces were planted deeper. Multiple studies indicate that green or sunburned tuber yield can be significantly reduced by increasing planting depth or through timely earthing up (Fanos et al., 2015). Therefore deducing from the above discussion timing of earthing up has a direct bearing to the number of greening tubers. Delayed or no earthing up exposes the tubers to light and hence greening of tubers increases this is in agreement with the results of the investigation which shows that 125 potato tubers were recorded from the control where there was no earthing up, the tubers were exposed to light and some ended up sprouting right in the field.

\section{Effects of time of earthing up on number of unmarketable tubers.}

Results of this experiment revealed that the delaying and no earthing-up resulted in higher percentage of unmarketable tubers. In this experiment unmarketable tuber yield was assessed by identifying under sized, damaged, diseased, deformed and green potato tubers (Tesfaye et al., 2012). A higher number (128) of affected tubers by disease, pests, size, malformed, greening tubers and pre harvest sprouting on tubers was observed in no earthing-up trials while 13 were recorded on EUBF ( 3 weeks) These results are in agreement with those produced by Fanos et al. (2015) who found out that unmarketable tuber yield from plots where earthing-up was done at 15 days was $16.55 \%$ lower than unmarketable tuber yield from no earthing up plots. From the investigation, earthingup at three weeks, four weeks five weeks and no earthing up showed reduced unmarketable tuber yield with early earthing up by $6 \%, 12 \%, 23 \%$ and $59 \%$, respectively. This is probably because of that which was explained by Svubure et al. (2015), denoting that exposing tubers outside of hill or tubers be shallow, less than $5 \mathrm{~cm}$ covered by soil make tubers prone to pest attack and greening which compromises tuber quality.

\section{Effects of time of earthing up on number of marketable tubers}

The highest number marketable tubers (152) was obtained at earthing up at EUBF ( 3 weeks) whereas 94, 59 and 33 were recorded from earthing up at $\operatorname{EAF}(4$ weeks), EUAF ( 5 weeks) and NEU (no earthing up) respectively. Results are in line to those found by Don and James (1990) who postulated that plants at EUBF (3 weeks) will quickly be covered and start tuber initiation on time, this leads to large sized tubers which are of good quality. The investigation showed that plant tubers from this stage of earthing up were always covered from the period of tuber initiation and thereafter which reduces their exposure to light, pest and diseases attack which greatly compromise tuber quality for marketability. The result of the current investigation are in line with the findings of Tesfaye et al. (2012) who rephrase earthing up as early as two weeks produces better yield of marketable tubers than that at 4weeks and no earthing up.

\section{Conclusion}

The current investigation showed that time of earthing up significantly affected both yield and all the four yield parameters (number of pest damaged tubers, number of greening potatoes, number of unmarketable tubers and number of marketable tubers). It can be concluded from this study that earthing up of potatoes before flowering ( 3 weeks) after full plant emergence is best preferable for attaining a higher yield and yield parameters. This study verified that yield and yield parameters of potato are influenced by time earthing up.

\section{Recommendations}

The researcher recommends that farmers should first earth up Irish potatoes before flowering in order to attain high yield and marketable yield.

\section{Acknowledgements}

The authors greatly acknowledge the assistance from Great Zimbabwe University lecturers and the farmer that provided the plot to carry out the experiment.

\section{Conflict of interest}

Authors do not declare any conflict of interest. 


\section{References}

Ackerman, K. (2012). Personal Communication.

Bouis, H. E., \& Scott, G. (1996). Demand for High Value Secondary Crops in Developing Countries. The Case of Potatoes in Bangladesh and Pakistan. International Food Policy Research Institute, Food and Consumption Division. Discussion Paper: Washington.

Burke, J. J. (2012). Growing the potato crop, Teagasc Crop Research Centre, Oak Park, Carlow: Ireland.

Fanos, T., Belew, D., \& Nebiyu, A. (2015). Effect of Planting Depth and Time of Earthing-up on Potato (Solanum Tuberosum L.) Yield and Yield Components at Jimma University College of Agriculture and Veterinary Medicine, South West Ethiopia. In International Journal of African and Asian Studies www.iiste.org ISSN (Vol. 15). Retrieved from www.iiste.org

FAO. (2008). Potato and biodiversity Factsheet. Global Crop Diversity Trust and FAO's Plant Production and Protection Division.

Food and Agricultural Organisation of the United Nations Statistics Division (FAOSTAT). (2012). http://faostat3.fao.org (accessed 07-10-2014).

FAOSTAT Statistics Division. (2012). FAO Journal. Fedotova L. S., Frolosova, A. V., Balabushevish, A. G. (2002). Potato become more testy due to the new fertilizer. No2:26-28. Int. J. Agric. Crop Science, 5(22), 2724-2731.

Gusha, S. (2014). From Potato Fields to Potato Sacks. Pastorial Response. Anglical Diocese of Harare: Zimbabwe.

Gutema, C. (2016). Effect of Earthing up Frequencies and Tuber Seed Form on Yield and Profitability of Potato (Solanum Tuberosum) Production in Bale Highlands. Agricultural Research \& Technology:Open Access Journal, 2(4). https://doi.org/10.19080/artoaj.2016.02.555592

Masvodza, R. (2015). Feasibility of Sack Potato Production as a New Technique used in Some Urban Parts of Zimbabwe. Journal of Agriculture and Ecology Research International, 3, 201-208.

Muhammad, Q., Salma K., Alia N., Muhammadzafarullah, K., \& Sohailahmad, K. (2013). Effects of different planting systems on yield of potato crop in kaghan valley: A mountainous region of Pakistan. Agricultural sciences, 4(4), 175-179.

Quin N. N. (2011). The Potato Contribution to Population and Distribution and Urbanisation Evidence from a Historical Experiment. Q. J. Econ., 126(2), 593-650.

Singh, B., \& Joshi, Y. C. (2016). Icreased potato productivity, its consequences and sustainable production. Retrieved from www.iaset.us

Svubure, O., Struik, P. C., Haverkort, A. J., \& Steyn, J. M. (2015). Yield gap analysis and resource footprints of Irish potato production systems in Zimbabwe. Field Crops Research, 178, 77-90. https://doi.org/10.1016/j.fcr.2015.04.002

Tafirt, S. A., Siyadat, R. R., \& Mojadama, M. (2010). Effects of Earthing up on the Potato Yeild in Dezful (Khouzestan, Iran) Weather Condition, Middle-East Journal Of Scientific Research.

Tamm, L. (2007). The Current Situation of Organic Potato Production in Europe. Switzerland Research Institute of Organic Agriculture: Switzerland.

Tesfaye, G., Derbew, B., \& Solomon, T. (2013). Combined Effect of Plant Spacing and Time of Earthing up on Tuber Quality Parameters of Potato (Solanum tuberosum L.) at Degem District, North Showa Zone of Oromia Regional State. Asian Journal of Crop Science, 5, 24-32.

The herald. (2011). October. High Costs of Production Frustrate Seed Potato Farmers, The Herald, Harare, Zimbabwe.

The Herald. (2012). May. Potato Declared Strategic Security Food Crop, The Herald, Harare, Zimbabwe.

\section{Copyrights}

Copyright for this article is retained by the author(s), with first publication rights granted to the journal.

This is an open-access article distributed under the terms and conditions of the Creative Commons Attribution license (http://creativecommons.org/licenses/by/4.0/). 